\title{
Analysis of MHC class II DP, DQ and DR alleles in Crohn's disease
}

A Cariappa, B Sands, D Forcione, D Finkelstein, D K Podolsky, S Pillai

\begin{abstract}
Background-Although inflammation in Crohn's disease is believed to be mediated by activated $T$ cells, genotyping of all MHC class II alleles in white people with this disease has not been reported.

Aims-To perform a detailed molecular analysis of HLA DPB, DQB, and DRB genes in white patients with Crohn's disease and controls in order to determine if the inheritance of any class II genes confers susceptibility or resistance to this disease.

Methods-Complete molecular typing of HLA class II DPB, DQB, and DRB alleles was performed in 58 white patients with Crohn's disease and 93 healthy controls using a polymerase chain reactionsequence specific oligonucleotide based approach.

Results-No significant association with any DPB or DQB alleles was noted in patients with Crohn's disease. Since our previous studies had shown a strong association of an HLA DRB3 ${ }^{\star} 0301 /$ DRB1`1302 haplotype with Crohn's disease, we re-examined this association using more stringent genotyping criteria. This haplotype was present in $20.7 \%$ of patients and $5.4 \%$ of controls $(p=0.0066$; relative risk $=4.59$ ).

Conclusions-The DRB3*0301/DRB1* 1302 haplotype is the only significant MHC class II association noted in white people with Crohn's disease and represents the strongest association of any MHC or non-MHC locus with this disease.

(Gut 1998;43:210-215)
\end{abstract}

Keywords: Crohn's disease; inflammatory bowel disease; genetic susceptibility; major histocompatibility complex; HLA class II genes

Cancer Center, Massachusetts General Hospital, Boston, MA 02129, USA

A Cariappa

D Forcione

D Finkelstein

S Pillai

Gastrointestinal Unit B Sands

D K Podolsky

Correspondence to: Dr S Pillai, MGH Cancer Center, Building 149, 13th Street, Charlestown Navy Yard, Boston, MA 02129, USA.

Accepted for publication 4 March 1998 important role in the disease process. Genetic susceptibility to Crohn's disease linked to HLA class II genes has been most striking in studies from Japan. In Japanese patients with Crohn's disease a strong positive association of the disease with DQB1*0401 and DQB ${ }^{\star} 0402$ has been observed, and a negative association of Crohn's disease with DQB $1{ }^{\star} 0102$ was noted. ${ }^{4}$

It remains unclear whether the inheritance of particular MHC class II alleles confers susceptibility to Crohn's disease in the white population. Most studies on MHC class II genes in white patients with Crohn's disease have involved the analysis of a limited number of alleles. ${ }^{3-9}$ In a recent study in which all DRB1, DRB3, DRB4, and DRB5 alleles were analysed using a polymerase chain reaction-sequence specific oligonucleotide (PCR-SSO) approach, we noted a strong association of Crohn's disease with $\mathrm{DRB}{ }^{\star} 0301 .{ }^{10}$ A significant association of Crohn's disease was also noted with $\mathrm{DRB} 1^{\star} 1302$. Every patient and control who inherited the DRB $1^{\star} 1302$ allele was also positive for DRB $3^{\star} 0301$. This was not surprising given that these two alleles are known to be tightly linked in the white population. ${ }^{11}$ In all the other studies referred to above, ${ }^{35-9}$ the DRB1*1302 and DRB3 ${ }^{\star} 0301$ alleles were not typed. In one recent European study in which more extensive typing was employed, a single MHC class II allele, DRB1*1302, was noted to be associated with disease ${ }^{12}$ (the linked DRB $3^{\star} 0301$ allele was not typed). This study provided independent corroboration of our previous analysis of DRB alleles and susceptibility to Crohn's disease. ${ }^{10}$

In this study we report the complete molecular typing of HLA class II DPB and DQB alleles in patients with Crohn's disease and ethnically matched healthy white controls. Apart from seeking to explore if there was any linkage of the disease to DPB or DQB alleles, we were interested in determining if our previously reported $\mathrm{DRB} 3^{\star} 0301$ and $\mathrm{DRB} 1^{\star} 1302$ associations in Crohn's disease reflected linkage disequilibrium to any DQB allele. In addition, our previous study had only used generic primers for the typing of the DRB3 locus, and complete concordance was not seen between DRB $3^{\star} 0301$ positivity and the inheritance of $\mathrm{DRB} 1{ }^{\star} 1302$, which was somewhat surprising. We were concerned that the approach to DRB3 typing used previously was not stringent enough and that typing with locus specific primers would provide a more accurate assessment of DRB3 allele frequencies. We therefore wished to test more stringently (using additional typing approaches not used in our previous study) the null hypothesis that the DRB1*1302/DRB3*0301 haplotype is linked to Crohn's disease in the white population. 


\section{Methods}

PATIENTS

Fifty eight consecutive white patients with Crohn's disease seen at the Center for the Study of Inflammatory Bowel Disease at Massachusetts General Hospital between January 1995 and November 1996 were included in the study. The diagnosis of Crohn's disease was made by conventional endoscopic, histological, and clinical criteria. Information on ethnicity was obtained from each patient. Retrospective clinical information was obtained for comparison from most of the patients. Information analysed included the age of onset, the existence of a family history of inflammatory bowel disease, anatomical sites of disease, the presence of fistulae or strictures, steroid dependence of the disease, and the presence of extraintestinal manifestations such as arthritis, uveitis, or erythema nodosum. Forty two of these patients had been included in our previous study. ${ }^{10}$

CONTROLS

The 93 healthy controls have been described previously and were all whites. ${ }^{10}$ Information on ethnicity was also obtained from controls.

MHC CLASS II TYPING

Genotyping of all DRB, DPB1, and DQB1 alleles was performed using a PCR-SSO approach according to the protocols described in the 11 th International HLA Workshop. ${ }^{13}$ Details of DRB typing have been described previously. ${ }^{10}$ Briefly, PCRs were performed in a total volume of $200 \mu \mathrm{l}$ and included $3 \mu \mathrm{l}$ genomic DNA, $200 \mathrm{pM}$ each primer, $0.2 \mathrm{mM}$ each deoxynucleotide triphosphate, $2 \mathrm{mM}$ $\mathrm{MgCl}_{2,}, 10 \mathrm{mM}$ Tris/HCl, pH 8.0, $50 \mathrm{mM}$ $\mathrm{KCl}, 0.001 \%(\mathrm{w} / \mathrm{v})$ gelatin and $2.5 \mathrm{U}$ Taq DNA polymerase (Fisher). Samples were denatured at $96^{\circ} \mathrm{C}$ for six minutes. Forty cycles of amplification sequentially involved incubation at $96^{\circ} \mathrm{C}$ for one minute followed by an annealing step for one minute (the temperature of which varied when different alleles were being analysed), and extension at $72^{\circ} \mathrm{C}$ for two minutes. After amplification, samples were incubated at $72^{\circ} \mathrm{C}$ for 10 minutes. The annealing temperature for the generic DRB1 alleles was 55 and $60^{\circ} \mathrm{C}$ for DRB1 and DRB3 group specific amplifications, $60^{\circ} \mathrm{C}$ for $\mathrm{DP}$ and $55^{\circ} \mathrm{C}$ for $\mathrm{DQ}$. A $10 \mu \mathrm{l}$ sample of the reaction mixture was run out on a $1.5 \%$ agarose gel, and the PCR products were viewed under UV light. Controls included previously typed samples. Generic typing of DRB1, DRB3, DRB4, and DRB5 loci was performed using a single pair of generic primers for PCR amplification followed by hybridisation of filters with 29 different group identifying SSOs. For group specific DRB typing, genomic DNA was amplified with five different 5' primers specific for DRB1-DR1, DRB1-DR2，DRB1-DR4， the DRB1-DR52 associated group and the DRB3-DR52 group. The 3' primer in the above cases was the same as that used for generic DRB typing. A total of 50 different SSOs was used in the group specific typing studies. Five SSOs were used for DRB1-DR1 (DRB1 $\left.{ }^{\star} 0101-03\right), 12$ for DRB1-
DR2 (DRB1*1501-03, DRB1*160102), nine for DRB1-DR4 (DRB1*0401-0411), 12 for the DRB1-DR52 associated group (DRB1* 0301/02, DRB1 ${ }^{\star} 0801-0804, \mathrm{DRB} 1{ }^{\star} 1101-04$, DRB1*1201/02, DRB1*1301-05, DRB1* 1401-08), and 12 SSOs were used for the DRB3-DR52 group (DRB3*0101, DRB3* 0201/0202 and DRB3*0301).

Generic primers were used for DPB1 and DQB1 typing; 25 SSOs were used to type 36 DPB1 alleles, and 20 SSOs for 17 DQB1 alleles. Details of the hybridisation conditions have been published. ${ }^{10}$ In brief, filters were prehybridised overnight at $54^{\circ} \mathrm{C}$ in buffer containing $3 \mathrm{M}$ tetramethylammonium chloride, $50 \mathrm{mM}$ Tris/ $\mathrm{HCl}, \mathrm{pH} 8.0,2 \mathrm{mM}$ EDTA, $5 \times$ Denhardt's solution, $0.1 \%$ sodium dodecyl sulphate (SDS), and $100 \mathrm{mg} / \mathrm{ml}$ salmon sperm DNA. Hybridisation was carried out using $\left[\gamma-{ }^{32} \mathrm{P}\right]$ ATP 5 ' labelled SSOs at $54^{\circ} \mathrm{C}$ for two hours. The filters were washed twice at room temperature for 15 minutes each in a solution containing $2 \times$ SSPE and $0.1 \%$ SDS followed by three washes for 10 minutes at $58^{\circ} \mathrm{C}$ in buffer containing $3 \mathrm{M}$ tetramethylammonium chloride, $50 \mathrm{mM}$ Tris $/ \mathrm{HCl}, 2 \mathrm{mM}$ EDTA, and $0.1 \%$ SDS. Each filter was exposed twice for autoradiography, once for one to two hours and subsequently for 14-16 hours. Reactivity was graded visually, using a scale recommended by the 11 th International HLA Workshop. ${ }^{13}$ The use of multiple oligonucleotide probes facilitated definitive identification of negative and positive alleles.

ANALYSIS OF DRB $3^{\star} 0301$

As noted above, in these studies we examined DRB3 alleles not only by the generic PCR amplification approach described previously ${ }^{10}$ but also using a separate 5 ' primer to amplify DRB3 alleles. A total of 12 SSOs was used for DRB3 typing using the specific PCR approach. Of these 12 , five reacted with $\mathrm{DRB} 3^{\star} 0301$ and two were specific for DRB3 ${ }^{\star} 0301$.

STATISTICAL ANALYSIS

Two tailed uncorrected $\mathrm{p}$ values were reported using Fisher's exact test for the analyses of MHC class II allele frequencies and for most comparisons of clinical information between $\mathrm{DRB} 1{ }^{\star} 1302 / \mathrm{DRB} 3{ }^{\star} 0301$ haplotype positive and negative patients. The relative risk was calculated as an odds ratio using the approximation of Woolf. ${ }^{14}$ For comparing mean ages of patients with Crohn's disease who were positive or negative for the DRB1*1302/ DRB $3^{\star} 0301$ haplotype, an unpaired Student's $t$ test was employed. $\mathrm{p}$ values were corrected for the number of comparisons essentially using a modified Bonferroni correction as suggested by Svejgaard and Ryder. ${ }^{15}$ The number of alleles assayed from a given specific PCR amplification was used as the basis for the number of comparisons made. Alleles for which the combined frequency in patients and controls was less than 1 were not included in the number of comparisons. In the case of the DPB1 locus, the number of comparisons made was 20 . Thus the nominal level for comparison was $\mathrm{p} \leqslant 0.0025$. In the case of the DQB1 locus, the 
Table 1 DPB1 alleles in patients with Crohn's disease and controls

\begin{tabular}{|c|c|c|c|}
\hline Allele & $\begin{array}{l}\text { Controls (\%) } \\
(n=90)\end{array}$ & $\begin{array}{l}\text { Crohn's disease } \\
(\%)(n=54)\end{array}$ & $p$ Value \\
\hline $\mathrm{DPB} 1{ }^{\star} 0101$ & $7.8(7)$ & $7.4(4)$ & 1.0000 \\
\hline $\mathrm{DPB} 1{ }^{\star} 0201$ & $18.9(17)$ & $33.3(18)$ & 0.0702 \\
\hline $\mathrm{DPB} 1{ }^{\star} 0202$ & $1.1(1)$ & $0.0(0)$ & 1.0000 \\
\hline $\mathrm{DPB} 1^{\star} 0301$ & $20.0(18)$ & $14.8(8)$ & 0.5068 \\
\hline $\mathrm{DPB} 1{ }^{\star} 0401$ & $50.0(45)$ & $53.7(29)$ & 0.7317 \\
\hline $\mathrm{DPB} 1{ }^{\star} 0402$ & $30.0(27)$ & $16.7(9)$ & 0.0783 \\
\hline $\mathrm{DPB} 1{ }^{\star} 0501$ & $0.0(0)$ & $5.6(3)$ & 0.0509 \\
\hline $\mathrm{DPB} 1{ }^{\star} 0601$ & $2.2(2)$ & $1.8(1)$ & 1.0000 \\
\hline $\mathrm{DPB} 1{ }^{\star} 0801$ & $1.1(1)$ & $0.0(0)$ & 1.0000 \\
\hline $\mathrm{DPB} 1{ }^{\star} 0901$ & $0.0(0)$ & $0.0(0)$ & - \\
\hline DPB $1^{\star} 1001$ & $7.8(7)$ & $5.6(3)$ & 0.7434 \\
\hline $\mathrm{DPB} 1 \star 1101$ & $2.2(2)$ & $3.7(2)$ & 0.6307 \\
\hline DPB $1^{\star} 1301$ & $4.4(4)$ & $3.7(2)$ & 1.0000 \\
\hline $\mathrm{DPB} 1 \star 1401$ & $4.4(4)$ & $1.8(1)$ & 0.6505 \\
\hline $\mathrm{DPB} 1{ }^{\star} 1501$ & $3.3(3)$ & $1.8(1)$ & 1.0000 \\
\hline $\mathrm{DPB} 1 \star 1601$ & $0.0(0)$ & $3.7(2)$ & 0.1390 \\
\hline $\mathrm{DPB} 1 \star 1701$ & $2.2(2)$ & $5.6(3)$ & 0.3636 \\
\hline DPB1* 1801 & $1.1(1)$ & $0.0(0)$ & 1.0000 \\
\hline DPB1*1901 & $1.1(1)$ & $0.0(0)$ & 1.0000 \\
\hline $\mathrm{DPB} 1{ }^{\star} 2001$ & $7.8(7)$ & $1.8(1)$ & 0.2586 \\
\hline $\mathrm{DPB} 1 \star 2101$ & $0.0(0)$ & $0.0(0)$ & - \\
\hline $\mathrm{DPB} 1{ }^{\star} 2201$ & $0.0(0)$ & $0.0(0)$ & - \\
\hline $\mathrm{DPB} 1{ }^{\star} 2301$ & $20.0(18)$ & $20.4(11)$ & 1.0000 \\
\hline $\mathrm{DPB} 1 \star 2401$ & $0.0(0)$ & $0.0(0)$ & - \\
\hline $\mathrm{DPB} 1{ }^{\star} 2501$ & $1.1(1)$ & $0.0(0)$ & 1.0000 \\
\hline $\mathrm{DPB} 1 \star 2601$ & $0.0(0)$ & $0.0(0)$ & - \\
\hline $\mathrm{DPB} 1 \star 2701$ & $3.3(3)$ & $3.7(2)$ & 1.0000 \\
\hline $\mathrm{DPB} 1 \star 2801$ & $0.0(0)$ & $0.0(0)$ & - \\
\hline DPB1*2901 & $1.1(1)$ & $1.8(1)$ & 1.0000 \\
\hline $\mathrm{DPB} 1{ }^{\star} 3001$ & $0.0(0)$ & $0.0(0)$ & - \\
\hline $\mathrm{DPB} 1 \star 3101$ & $0.0(0)$ & $1.8(1)$ & 0.3750 \\
\hline $\mathrm{DPB} 1 \star 3201$ & $0.0(0)$ & $3.7(2)$ & 0.1390 \\
\hline $\mathrm{DPB} 1 \star 3301$ & $0.0(0)$ & $1.8(1)$ & 0.3750 \\
\hline DPB1*3401 & $0.0(0)$ & $0.0(0)$ & - \\
\hline $\mathrm{DPB} 1 \star 3501$ & $2.2(2)$ & $0.0(0)$ & 0.5280 \\
\hline $\mathrm{DPB} 1 \star 3601$ & $1.1(1)$ & $0.0(0)$ & 1.0000 \\
\hline
\end{tabular}

Values in parentheses are numbers.

number of comparisons made was 13 and the nominal level for comparison was $\mathrm{p} \leqslant 0.0038$. In the case of the DRB1 locus, the number of comparisons was 26 and the nominal level for comparison was $p \leqslant 0.0019$. In the case of the DRB3, 4, and 5 loci, the number of comparisons was six and the nominal level for comparison was $\mathrm{p} \leqslant 0.0083$.

\section{Results}

Detailed molecular typing failed to disclose any statistically significant associations of DPB1 alleles with Crohn's disease (table 1). However, weak positive associations were noted with $\mathrm{DPB} 1{ }^{\star} 0201(\mathrm{p}=0.0702)$ and $\mathrm{DPB} 1{ }^{\star} 0501(\mathrm{p}$ $=0.0509$ ), and a weak negative association was noted with DPB $1^{\star} 0402(\mathrm{p}=0.0783)$. Some of these associations may attain significance in a study with more power. Analysis of DQB alleles (table 2) showed weak associations in Crohn's disease with DQB $1^{\star} 0201$ ( $\mathrm{p}=$ $0.0168)$ and $\mathrm{DQB} 1{ }^{\star} 0605(\mathrm{p}=0.0226)$. We believe that these weak DQB associations reflect the known linkage of these $\mathrm{DQB}$ alleles to DRB1 ${ }^{\star} 1302$ in the white population. ${ }^{16}$ Weak negative associations were also noted with $\mathrm{DQB} 1^{\star} 03032(\mathrm{p}=0.0883)$ and DQB ${ }^{\star} 05031$ $(\mathrm{p}=0.0883)$; these might acquire more significance in a larger study.

On this extended series of patients, a weak negative association of $\mathrm{DRB} 1{ }^{\star} 0401$ ( $\mathrm{p}=$ 0.0173 ) was noted in patients with Crohn's disease (table 3). This association ceases to be statistically significant after corrections are made for the number of comparisons (adjusted nominal level is $\mathrm{p} \leqslant 0.0019)$. This negative
Table 2 DQB1 alleles in patients with Crohn's disease and controls

\begin{tabular}{|c|c|c|c|}
\hline Allele & $\begin{array}{l}\text { Controls (\%) } \\
(n=86)\end{array}$ & $\begin{array}{l}\text { Crohn's disease } \\
(\%)(n=56)\end{array}$ & p Value \\
\hline $\mathrm{DQB} 1{ }^{\star} 0201$ & $24.4(21)$ & $44.6(25)$ & 0.0168 \\
\hline DQB1*0301 & $46.5(40)$ & $33.9(19)$ & 0.1646 \\
\hline DQB $1{ }^{\star} 0302$ & $19.8(17)$ & $21.4(12)$ & 0.8337 \\
\hline DQB $1{ }^{\star} 03031$ & $0.0(0)$ & $0.0(0)$ & - \\
\hline $\mathrm{DQB} 1{ }^{\star} 03032$ & $9.3(8)$ & $1.8(1)$ & 0.883 \\
\hline $\mathrm{DQB} 1{ }^{\star} 0401$ & $0.0(0)$ & $0.0(0)$ & - \\
\hline DQB1 ${ }^{\star} 0402$ & $4.7(4)$ & $7.1(4)$ & 0.7122 \\
\hline $\mathrm{DQB} 1{ }^{\star} 0501$ & $18.6(16)$ & $10.7(6)$ & 0.2418 \\
\hline DQB1*0502 & $4.7(4)$ & $1.8(1)$ & 0.6483 \\
\hline DQB $1{ }^{\star} 05031$ & $9.3(8)$ & $1.8(1)$ & 0.0883 \\
\hline $\mathrm{DQB} 1{ }^{\star} 05032$ & $0.0(0)$ & $0.0(0)$ & - \\
\hline DQB1 10504 & $0.0(0)$ & $0.0(0)$ & - \\
\hline DQB1*0601 & $1.2(1)$ & $3.6(2)$ & 0.5619 \\
\hline $\mathrm{DQB} 1{ }^{\star} 0602$ & $26.7(23)$ & $19.6(11)$ & 0.4219 \\
\hline $\mathrm{DQB} 1{ }^{\star} 0603$ & $11.6(10)$ & $10.7(6)$ & 1.0000 \\
\hline $\mathrm{DQB} 1{ }^{\star} 0604$ & $4.7(4)$ & $12.5(7)$ & 0.1185 \\
\hline DQB1*0605 & $0.0(0)$ & $7.1(4)$ & 0.0226 \\
\hline
\end{tabular}

Values in parentheses are numbers.

association may attain more significance in a larger study. One of the major goals of this study was to test the null hypothesis that Crohn's disease in whites is linked to DRB ${ }^{\star} 0301$ or to a DRB3 ${ }^{\star} 0301 / \mathrm{DRB} 1^{\star} 1302$ haplotype. In our previous report we had analysed the DRB ${ }^{\star} 0301$ allele only using generic primers in the amplification step. We had used one set of generic primers to analyse DRB1 alleles and the DRB3, 4, and 5 loci, before evaluating PCR products with a range of probes. Although subsequent specific PCRs were performed to assay groups of DRB1 alleles, specific amplification of the DRB3 locus had not been performed. While every subject in that study who tested positive for the DRB $1 \star 1302$ allele was also positive for DRB $3^{\star} 0301$, a few patients who were typed for DRB $3^{\star} 0301$ apparently did not carry a $\mathrm{DRB} 1{ }^{\star} 1302$ allele. Given the known tight linkage of $\mathrm{DRB} 1^{\star} 1302$ to $\mathrm{DRB} 3^{\star} 0301$, this lack of concordance was puzzling. We sought to assay for $\mathrm{DRB} 3^{\star} 0301$ more stringently in this extended group of patients with Crohn's disease and in controls. Accordingly, we performed a specific PCR for DRB3 alleles and probed this PCR product with 12 separate SSOs as described under Methods. Using these criteria every patient or control inheriting a DRB $1^{\star} 1302$ allele was also noted to have inherited a DRB $3^{\star} 0301$ allele (tables 3 and 4 ). Four patients who had previously been categorised as being $\mathrm{DRB} 3{ }^{\star} 0301$ positive in our previous study ${ }^{10}$ but who were negative for the DRB $1^{\star} 1302$ allele were found to be negative for $\mathrm{DRB}^{\star}{ }^{\star} 0301$ using the more stringent criteria described above. A strong association with the $\mathrm{DRB} 1^{\star} 1302 / \mathrm{DRB} 3^{\star} 0301$ haplotype was noted in patients with Crohn's disease $(\mathrm{p}=$ 0.0066; relative risk 4.59). Given that the DRB1*1302/DRB3*0301 haplotype was specifically targeted for analysis by our initial hypothesis, corrections for the number of comparisons made were not called for. Nonetheless, the above $p$ value $(p=0.0066)$ is less than the corrected nominal value of $p \leqslant 0.0083$ (for the DRB3 locus), and it should be considered that individuals with this haplotype are at a significantly increased risk for Crohn's disease. 
Table 3 DRB1 alleles in patients with Crohn's disease and controls

\begin{tabular}{|c|c|c|c|c|}
\hline Allele & & $\begin{array}{l}\text { Controls }(\%) \\
(n=93)\end{array}$ & $\begin{array}{l}\text { Crohn's } \\
\text { disease (\%) } \\
(n=58)\end{array}$ & p Value \\
\hline \multirow[t]{3}{*}{ DR1 } & $\star 0101$ & $10.8(10)$ & $10.3(6)$ & 1.0000 \\
\hline & $\star 0102$ & $6.5(6)$ & $3.4(2)$ & 0.7111 \\
\hline & $\star 0103$ & $4.3(4)$ & $1.7(1)$ & 0.6494 \\
\hline \multirow[t]{5}{*}{ DR2 } & $\star 1501$ & $25.8(24)$ & 24.1 (14) & 0.8497 \\
\hline & $\star 1502$ & $1.1(1)$ & $3.4(2)$ & 0.5589 \\
\hline & $\star 1503$ & $0.0(0)$ & $0.0(0)$ & - \\
\hline & $\star 1601$ & $4.3(4)$ & $1.7(1)$ & 0.6494 \\
\hline & ^1602 & $0.0(0)$ & $0.0(0)$ & - \\
\hline DR3 & ${ }^{\star} 0301-02$ & $17.2(16)$ & $17.2(10)$ & 1.0000 \\
\hline \multirow{11}{*}{ DR4 } & $\star 0401$ & $12.9(12)$ & $1.7(1)$ & 0.0173 \\
\hline & $\star 0402$ & $6.5(6)$ & $10.3(6)$ & 0.5376 \\
\hline & $\star 0403$ & $2.2(2)$ & $0.0(0)$ & 0.5237 \\
\hline & $\star_{0} 0404$ & $5.4(5)$ & $8.6(5)$ & 0.5084 \\
\hline & $\star 0405$ & $0.0(0)$ & $3.4(2)$ & 0.1460 \\
\hline & $\star 0406$ & $0.0(0)$ & $0.0(0)$ & - \\
\hline & $\star 0407$ & $5.4(5)$ & $0.0(0)$ & 0.1569 \\
\hline & $\star 0408$ & $1.1(1)$ & $1.7(1)$ & 1.0000 \\
\hline & $\star 0409$ & $0.0(0)$ & $0.0(0)$ & - \\
\hline & $\star 0410$ & $0.0(0)$ & $0.0(0)$ & - \\
\hline & ${ }^{\star} 0411$ & $0.0(0)$ & $0.0(0)$ & - \\
\hline DR7 & $\star^{\star} 0701$ & $16.1(15)$ & 25.9 (15) & 0.2078 \\
\hline DR8 & ${ }^{\star} 0801-04$ & $4.3(4)$ & $5.2(3)$ & 1.0000 \\
\hline DR9 & $\begin{array}{l}{ }^{\star} 0901 \mathrm{~A} / \\
\mathrm{B}\end{array}$ & $1.1(1)$ & 1.7 (1) & 1.0000 \\
\hline DR10 & $\star 1001$ & $1.1(1)$ & $0.0(0)$ & 1.0000 \\
\hline \multirow[t]{4}{*}{ DR11 } & $\star 1101$ & $15.0(14)$ & $8.6(5)$ & 0.3169 \\
\hline & $\star 1102$ & $1.1(1)$ & $1.7(1)$ & 1.0000 \\
\hline & $\star 1103$ & $2.2(2)$ & $8.6(5)$ & 0.1075 \\
\hline & $\star 1104$ & $8.6(8)$ & $10.3(6)$ & 0.7767 \\
\hline DR12 & $\star 1201-02$ & $5.4(5)$ & $3.4(2)$ & 0.7079 \\
\hline \multirow[t]{5}{*}{ DR13 } & $\star 1301$ & $10.8(10)$ & $6.9(4)$ & 0.5679 \\
\hline & *1302 & $5.4(5)$ & 20.7 (12) & $0.0066 \dagger$ \\
\hline & $\star 1303$ & $1.1(1)$ & $1.7(1)$ & 1.0000 \\
\hline & $\star 1304$ & $0.0(0)$ & $0.0(0)$ & - \\
\hline & $\star 1305$ & $0.0(0)$ & $1.7(1)$ & 0.3841 \\
\hline \multirow[t]{8}{*}{ DR14 } & $\star 1401$ & $9.7(9)$ & $3.4(2)$ & 0.2053 \\
\hline & $\star 1402$ & $0.0(0)$ & $0.0(0)$ & - \\
\hline & $\star 1403$ & $1.1(1)$ & $0.0(0)$ & 1.0000 \\
\hline & ^1404 & $2.2(2)$ & $0.0(0)$ & 0.5237 \\
\hline & ^1405 & $0.0(0)$ & $0.0(0)$ & - \\
\hline & $\star 1406$ & $0.0(0)$ & $0.0(0)$ & - \\
\hline & $\star 1407$ & $0.0(0)$ & $0.0(0)$ & - \\
\hline & $\star 1408$ & $0.0(0)$ & $0.0(0)$ & - \\
\hline
\end{tabular}

Values in parentheses are numbers. $†$ This allele was the target of our null hypothesis.

Table 4 DRB3 DRB4 and DRB5 alleles in patients with Crohn's disease and controls

\begin{tabular}{lcll}
\hline Allele & $\begin{array}{l}\text { Controls (\%) } \\
(n=93)\end{array}$ & $\begin{array}{l}\text { Crohn's disease } \\
(\%)(n=58)\end{array}$ & $p$ Value \\
\hline $\begin{array}{l}\text { DRB3 } \\
{ }^{\star} 0101\end{array}$ & $23.7(22)$ & $12.1(7)$ & 0.0919 \\
${ }^{\star} 0201 /$ & $46.2(43)$ & $55.2(32)$ & 0.3180 \\
${ }^{\star} 0202$ & & & \\
${ }^{*} 0301$ & $5.4(5)$ & $20.7(12)$ & $0.0066 \dagger$ \\
$\begin{array}{l}\text { DRB4 } \\
{ }^{\star} 0101\end{array}$ & $45.2(42)$ & $46.6(27)$ & 0.8685 \\
$\begin{array}{l}\text { DR5 } \\
{ }^{\star} 0101\end{array}$ & $28.0(26)$ & $25.9(15)$ & 0.8519 \\
${ }^{\star} 0102 /{ }^{*} 02$ & $3.2(3)$ & $5.2(3)$ & 0.6758
\end{tabular}

Values in parentheses are numbers. $†$ This allele was the target of our null hypothesis.

Figure 1 shows representative assays for the molecular typing of HLA DP, DQ, and DR alleles.

It has been pointed out that susceptiblity alleles for inflammatory bowel disease may vary between ethnic groups. ${ }^{17}$ Compared with other North American studies, a larger proportion of our white patients with Crohn's disease are non-Jewish. However, the frequency of the DRB ${ }^{\star}{ }^{*} 1302 / \mathrm{DRB} 3{ }^{\star} 0301$ haplotype in Jewish patients with Crohn's disease $(13.33 \%, \mathrm{n}=15)$ and non-Jewish patients with Crohn's disease $(23.25 \%, \mathrm{n}=43)$ was not significantly different $(\mathrm{p}=0.7123)$. We have attempted to correlate the inheritance of this haplotype in our patients
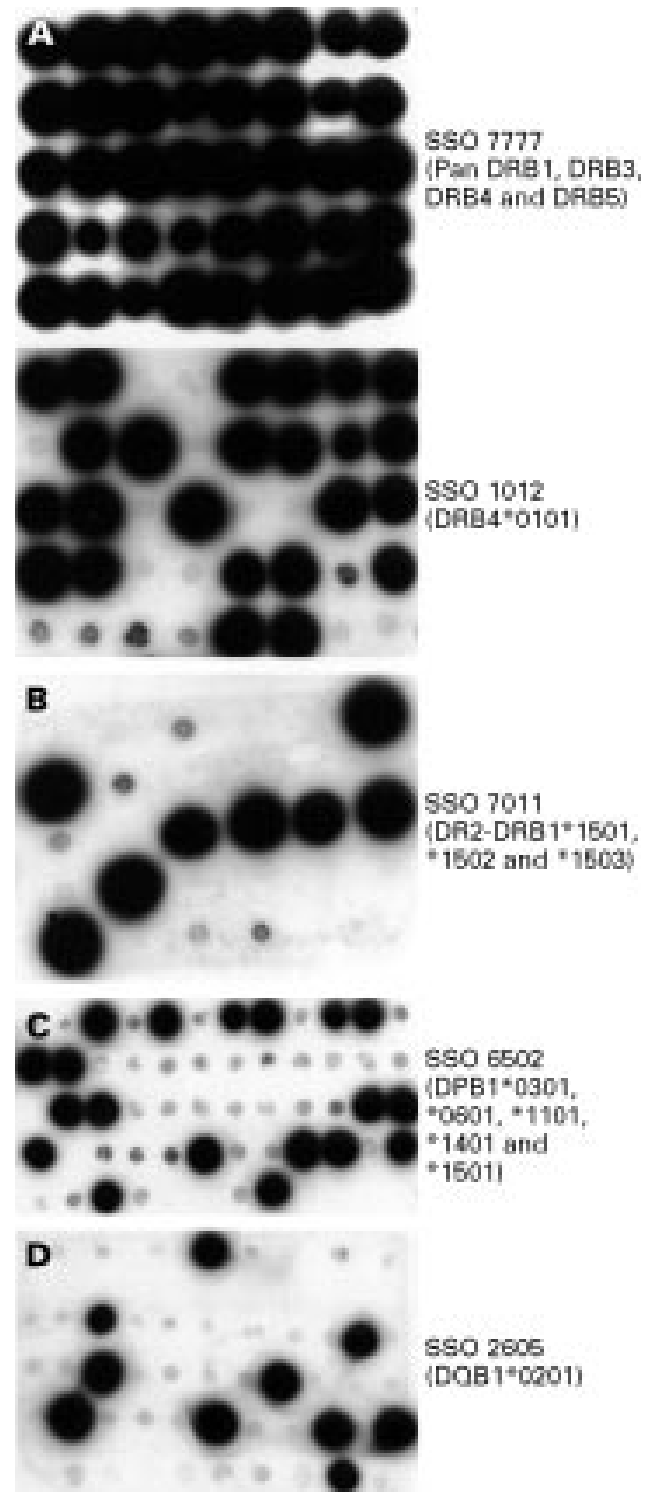

Figure 1 Representative SSO-PCR analyses for HLA $D P, D Q$, and $D R$ alleles. (A) A representative filter depicting generic $D R B$ typing for groups of $D R B 1, D R B 3$, DRB4, and DRB5 alleles. Upper panel: dot blot hybridisation of a representative filter with a pan DRB probe to show the presence of amplified DNA in each spot on replicate filters. A total of 40 Crohn's disease and control samples were spotted on this filter. Lower panel: a replicate of the filter depicted in the upper panel was probed with an SSO specific for DRB4*0101. Amplified DNA that hybridised or failed to hybridise with the SSO may be visually distinguished (24 of the 40 spots containing amplified DNA hybridised with this probe). (B) $A$ representative filter depicting group specific DRB typing for the DRB1-DR2 group. A separate PCR amplification for the DRB1-DR2 group was performed and a representative filter was probed with an SSO that is specific for some members of this group (DRB1*1501, DRB1*1502, and $\left.D R B 1^{\star} 1503\right)$. Multiple SSO probes were used to type all the alleles in each group. Eight of the 27 samples were revealed by this probe. (C) A representative filter depicting generic DPB1 typing using an SSO that can reveal five DPB1 alleles; 19 of 54 samples (from normal controls) were hybridised with this specific probe. (D) A representative filter depicting generic $D Q$ typing of normal controls. This filter was probed with an SSO specific for $D Q B 1{ }^{\star} 0201 ; 10$ of 50 samples were revealed by this probe.

with a number of clinical parameters listed in table 5. No significant correlation was seen with the anatomical extent of the disease, the presence of stricturing or fistulating disease, 
Table 5 Comparison of clinical characteristics of DRB1 $1302 / D R B 3{ }^{\star} 0301$ positive and negative patients with Crohn's disease

\begin{tabular}{llll}
\hline & $\begin{array}{l}\text { DRB1*1302 } \\
\text { positive }\end{array}$ & $\begin{array}{l}\text { DRB1*1302 } \\
\text { negative }\end{array}$ & p Value \\
\hline Age at diagnosis & $22.7(\mathrm{n}=10)$ & $29.4(\mathrm{n}=35)$ & $0.18 \dagger$ \\
Small bowel (\%) & $80(8 / 10)$ & $88.9(32 / 36)$ & 0.5975 \\
Large bowel (\%) & $80(8 / 10)$ & $63.9(23 / 36)$ & 0.4599 \\
Small and large bowel (\%) & $60(6 / 10)$ & $52.8(19 / 36)$ & 0.7348 \\
Fistulae (\%) & $50(5 / 10)$ & $56.8(21 / 37)$ & 0.7339 \\
Strictures (\%) & $20(2 / 10)$ & $37.1(13 / 35)$ & 0.4556 \\
Extraintestinal manufestations (\%) & $33.3(3 / 9)$ & $17.6(6 / 34)$ & 0.3668 \\
Steroid dependency (\%) & $20(2 / 10)$ & $42.8(15 / 35)$ & 0.2759 \\
\hline
\end{tabular}

tThe $\mathrm{p}$ value for this row was calculated from an unpaired Student's $t$ test. All other p values in this table were based on Fisher's exact test.

Table 6 Summary of HLA class II associations in white patients with Crohn's disease

\begin{tabular}{lll}
\hline Strong positive association & Weak positive association & Weak negative association \\
\hline $\mathrm{DRB} 1^{\star} 1302 / \mathrm{DRB} 3{ }^{\star} 0301(\mathrm{p}=0.0066)$ & $\mathrm{DPB} 1^{\star} 0201(\mathrm{p}=0.0702)$ & $\mathrm{DRB} 1^{\star} 0401(\mathrm{p}=0.0173)$ \\
& $\mathrm{DPB} 1^{\star} 0501(\mathrm{p}=0.0509)$ & $\mathrm{DPB} 1^{\star} 0402(\mathrm{p}=0.0783)$ \\
& $\mathrm{DQB} 1^{\star} 0201(\mathrm{p}=0.0168)$ & $\mathrm{DQB} 1^{\star} 03032(\mathrm{p}=0.0883)$ \\
& $\mathrm{DQB} 1^{\star} 0605(\mathrm{p}=0.0226)$ & $\mathrm{DQB} 1^{\star} 05031(\mathrm{p}=0.0883)$
\end{tabular}

steroid dependency, or the presence of extraintestinal manifestations. A trend was noted towards an earlier age of onset (mean age 22.7 years) in patients who inherited this haplotype than in those who did not (mean age 29.4 years). The two tailed $\mathrm{p}$ value (derived by an unpaired Student's $t$ test) for this comparison was 0.18 , which is not significant.

Table 6 summarises selected results of weak and strong HLA class II associations with Crohn's disease.

\section{Discussion}

The lesions in Crohn's disease result from the activation of inflammatory $\mathrm{T}$ cells by peptides presented by MHC class II molecules which may or may not be of host origin. It is of some interest that persistent clonal expansions of peripheral CD4 $\mathrm{T}$ cells have been noted in patients with Crohn's disease. ${ }^{18} 19$ Given the importance of $\mathrm{T}$ cell mediated inflammation in Crohn's disease, there is little doubt that MHC class II molecules play a critical role in the disease process. Whether or not specific MHC class II alleles are linked to the disease is another issue.

Making confident assertions about the presence or absence of the association of MHC class II alleles with a disease depends not only on proper patient selection, but also on the accurate typing of all known alleles at each of the polymorphic HLA class II loci. The ideal study would involve the analysis of all known DP, DQ, and DR alleles in a very large number of carefully characterised patients and controls. The larger the number of subjects the more likely less frequent associations will be detected. Even in a study of a large number of patients, if an allele that is associated with disease in a fair proportion of patients is not typed, such an association will obviously be missed. This is an important limitation of a number of previous studies on MHC genes and susceptibility to Crohn's disease. The present report represents the most comprehensive analysis of DP, DQ, and DR alleles in this disease.

Although we noted no significant association of Crohn's disease with DPB or DQB alleles, it is possible that these alleles present peptides of pathogenic significance in a relatively small number of patients. In a substantial proportion of white patients with Crohn's disease, the disease is clearly linked to inheritance of the DRB $1{ }^{\star} 1302 / \mathrm{DRB}^{\star}{ }^{\star} 0301$ haplotype. Our more stringent analyses in this study have confirmed the findings in our previous report. ${ }^{10}$ In that study, association of Crohn's disease with the $\mathrm{DRB}^{\star}{ }^{\star} 1302 / \mathrm{DRB} 3^{\star} 0301$ haplotype was actually less significant $(\mathrm{p}=0.0234$; relative risk 4.1412) than the association seen in the present study. The association seen with DRB ${ }^{\star} 0301$ alone in that study appeared stronger $(p=0.0004$; relative risk 7.04$)$, but we recognise that these results were inaccurate and reflect the less stringent methods used at the time for the analysis of the DRB $3^{\star} 0301$ allele.

It is of interest that in the only other study on white patients with Crohn's disease in which the DRB $1^{\star} 1302$ allele was actually typed, ${ }^{12}$ this proved to be the only allele associated with disease. In that study by Heresbach et $a l,{ }^{12}$ additional susceptibility loci were identified by examining clinical subgroups of patients with Crohn's disease. In our continuing studies we will seek to analyse MHC class II associations in similar clinical categories of subjects drawn from a larger set of patients with Crohn's disease.

The detection of associations between the inheritance of specific alleles and disease was limited in this study by the number of subjects studied; we note that on the basis of 58 cases and a two sided 0.05 level test, we had about $80 \%$ power to detect a difference of $20 \%$ in the frequency of inheritance of a given haplotype in patients versus controls (for example $25 \%$ in patients versus $5 \%$ in controls). The power to detect differences of $15 \%$ was only about $60 \%$. In our study therefore we were able to detect only strong associations. When the Bonferroni correction is made for the number of comparisons, the power is much lower, suggesting that the associations actually noted are likely to be seen as even more significant in a larger study. It is therefore possible that a number of additional significant associations of $\mathrm{MHC}$ class II alleles with Crohn's disease (other than the strong DRB3*0301/DRB1*1302 association confirmed in this study) will be noted in a study with more power.

An association between an HLA class II gene and a disease syndrome does not necessarily imply that the linked class II heterodimeric product is directly involved in the disease process. In principle, such an association may reflect linkage to another HLA gene, linkage to a non-HLA gene that is relevant to immune function, or even to some other gene on chromosome 6 which has no direct bearing on the immune system. An example of the latter category is the linkage disequilibrium between a haplotype including HLA B47 and the 21-hydroxylase gene on chromosome 6 in patients with one form of congenital adrenal hyperplasia. ${ }^{20}$ In a number of autoimmune or chronic inflammatory diseases, inflammation is driven by helper $T$ cells and susceptibility is linked to multiple loci, most of which are not 
on chromosome 6 . In diseases that fall into this category, strong associations with a limited number of MHC class II alleles have generally been noted. In white patients with multiple sclerosis, susceptibility to the disease is often linked to $\mathrm{DRB} 1^{\star} 1501,{ }^{21}{ }^{22}$ and in type I diabetes suceptibility is associated primarily with the $\mathrm{DRB} 1^{\star} 04 / \mathrm{DQB} 1^{\star} 0302$ and DRB $1{ }^{\star} 0301 / \mathrm{DQB} 1{ }^{\star} 0201$ haplotypes. ${ }^{23}{ }^{24}$ In these conditions, self antigen derived peptides are presented by these disease associated HLA class II molecules to helper $\mathrm{T}$ cells which are likely to be of pathogenic importance. ${ }^{25} 26$ There is growing evidence for the abrogation of $\mathrm{T}$ cell tolerance in such states by a process of molecular mimicry initiated by specific infectious agents which may trigger self reactive $T$ cells. ${ }^{27}$ Although there is no convincing evidence to suggest that Crohn's disease is an autoimmune disease, it is nevertheless likely that inflammation is driven by helper $\mathrm{T}$ cells responding to peptides of pathogenic significance presented by disease related HLA class II molecules. An alternative possibility is that disease linked HLA class II molecules may not directly be linked to the induction of inflammation in Crohn's disease, but that the inheritance of a susceptibility allele may predispose individuals to infection by some unidentified microbial agent. This infection may, in turn, be responsible for the induction of disease related inflammatory $\mathrm{T}$ cells by molecular mimicry.

One of the indirect conclusions that we can draw from this study is that peptides that may be of pathogenic significance in Crohn's disease in the white population may be presented by a large number of MHC class II alleles that are fairly widely distributed in the population. Certain peptides of disease significance may be preferentially presented by either $\mathrm{DRB}^{\star} 0301$ or $\mathrm{DRB} 1^{\star} 1302$. Linkage to this haplotype may reflect an actual role for one or both of these alleles, but may also reflect linkage disequilibrium to some other nonMHC gene. It clearly does not represent linkage disequilibrium to an MHC class II DQB allele. In any event, the association that we note with this particular haplotype represents a much stronger association (in terms of its frequency in affected white patients with Crohn's disease) than any non-MHC linked locus currently identified. Given the association of disease with specific susceptibility alleles in a less heterogeneous Japanese Crohn's disease population, ${ }^{4}$ it is quite likely that this result reflects a real MHC class II susceptibility haplotype for white patients with Crohn's disease.

We thank all the patients who volunteered for this study and their referring clinicians. This work was supported by grants AI-33507 and P30DK43351 from the National Institutes of Health and by the core facilities of the Center for the Study of Inflammatory Bowel Disease, Massachusetts General Hospital.

1 Hugot J-P, Laurent-Puig P, Gower-Rousseau C, et al. Mapping of a susceptibility locus for Crohn's disease on chromosome 16. Nature 1996;379:821-3.
2 Ohmen JD, Yang HY, Yamamoto KK, et al. Susceptibility locus for inflammatory bowel disease on chromosome 16 has a role in Crohn's disease but not in ulcerative colitis. Hum Mol Genet 1996;5:1679-83.

3 Satsangi J, Welsh KI, Bunce M, et al. Contribution of genes of the major histocompatibility complex to susceptibility and disease phenotype in inflammatory bowel disease. Lancet 1996;347:1212-17.

4 Nakajima A, Matsuhashi N, Kodama T, et al. HLA linked susceptibility and resistance genes in Crohn's disease. Gastroenterology 1995;109:1462-7.

5 Zetterquist H, Broome U, Einarsson K, et al. HLA class II genes in primary sclerosing cholangitis and chronic inflammatory bowel disease: no HLA-DRw52a association in Swedish patients with sclerosing cholangitis. Gut 1992;33: 942-6.

6 Wassmuth R, Eastman S, Kockum I, et al. HLA DR and DQ RFLP analysis in Crohn's disease. Eur $\mathcal{f}$ Immunogenet 1993;20:429-33.

7 Toyoda H, Wang S, Yang H, et al. Distinct associations of HLA class II genes with inflammatory bowel disease. Gastroenterology 1993;109:1462-7.

8 Danze P-M, Colombel J-F, Jacquot S, et al. Association of HLA class II genes with susceptibility to Crohn's disease. Gut 1996;39:69-72.

9 Reinshagen M, Loeliger C, Kuehnl P, et al. HLA class II frequencies in Crohn's disease: a population based analysis in Germany. Gut 1996;38:538-42.

10 Forcione DG, Sands B, Isselbacher KJ, et al. An increased risk of Crohn's disease in individuals who inherit the HLA class II DRB3 ${ }^{\star} 0301$ allele. Proc Natl Acad Sci USA 1996;93:5094-8.

11 Gorski J, Tilanus M, Giphart M, et al. Oligonucleotide genotyping shows that alleles at the HLA DRB3 locus of the DRw52 supertypic group segregate independently of the DRw52 supertypic group segregate independently of 83.

12 Heresbach D, Alizadeh M, Bretagne JF, et al. Investigation of the association of major histocompatibility complex genes including HLA class I, class II and TAP genes with clinical forms of Crohn's disease. Eur f Immunogenet 1996; 23:141-51.

13 Kimura A, Sasazuki T. Eleventh International Histocompatibility Workshop: protocol for the HLA DNA typing technique. In: Tsuji K, Aizawa M, Sasazuki T, eds. HLA 1991. Proceedings of the Eleventh International Histocompatibility Workshop and Conference. Volume 1. New York and Oxford: 1992:397-418.

14 Woolf $\mathrm{B}$. On estimating the relationship between blood group and disease. Ann Hum Genet 1955;19:251-3.

15 Svejgaard A, Ryder LP. HLA and disease associations: detecting the strongest association. Tissue Antigens 1994;43: $18-27$.

6 Imanishi T, Akaza T, Kimura A, et al. Allele and haplotype frequencies for HLA and complement loci in various ethnic groups. In: Tsuji K, Aizawa M, Sasazuki T, eds. HLA 1991. Proceedings of the Eleventh International Histocompatibility Workshop and Conference. Volume 1. New York and Oxford: 1992:1065-220.

17 Duerr RH, Neigut DA. Molecularly defined HLA-DR2 alleles in ulcerative colitis and an anti-neutrophil cytoplasmic antibody positive subgroup. Gastroenterology 1995;109: $1462-7$

18 Gulwani-Akolkar B, Akolkar PN, McKinley M, et al. Crohn's disease is accompanied by changes in the CD4+, but not CD8+ $\mathrm{T}$ cell receptor $\mathrm{Vb}$ repertoire of lamina propria lymphocytes. Clin Immunol Immunopathol 1995;77:95106.

19 Probert CS, Chott A, Turner JR, et al. Persistent expansions of peripheral blood CD4+ lymphocytes in chronic inflammatory bowel disease. F Immunol 1996;157:3183-91.

20 Miller WL, Morel Y. The molecular genetics of 21hydroxylase deficiency. Annu Rev Genet 1989;23:371-93.

21 Spielman RS, Nathenson N. The genetics of susceptibility to multiple sclerosis. Epidemiol Rev 1982;4:45-65.

22 Olerup O, Hillert J, Fredrickson S, et al. Primary chronic progressive and relapsing/remitting multiple sclerosis: two immunogenetically distinct disease entities. Proc Natl Acad Sci USA 1989;86:7113-17.

23 Todd JA, Farrall M. Panning for gold: genome-wide scanning for linkage in type I diabetes. Hum Mol Genet 1996;5:1443-8

24 Nepom GT, Erlich H. MHC class II molecules and autoimmunity. Annu Rev Immunol 1992;9:493-525.

25 Ota K, Matsui M, Milford EL, et al. T cell recognition of an immunodominant myelin basic protein epitope in multiple sclerosis. Nature 1990;346:183-7.

26 Roep BO. T cell responses to autoantigens in IDDM: the search for the Holy Grail. Diabetes 1996;45:1147-56.

27 Wucherpfennig KW, Strominger JC. Molecular mimicry in $\mathrm{T}$ cell mediated autoimmunity: viral peptides activate human $\mathrm{T}$ cell clones specific for myelin basic protein. Cell 199580:695-705. 